\title{
A COMPARISON OF SPORTING ACTIVITIES ACROSS THE VISEGRAD GROUP COUNTRIES
}

\section{PORÓWNANIE AKTYWNOŚCI SPORTOWEJ W KRAJACH GRUPY WYSZEHRADZKIEJ}

\author{
Tamás Laczkó ${ }^{1(\mathrm{~A}, \mathrm{C}, \mathrm{D}, \mathrm{E})}$, Alexandra Makai ${ }^{(\mathrm{A}, \mathrm{E}, \mathrm{F})}$, \\ Viktória Prémusz ${ }^{1(\mathrm{~A}, \mathrm{E}, \mathrm{F})}$, Pongrác Ács ${ }^{1 \mathrm{~A}, \mathrm{G})}$, Dávid Paár ${ }^{1(\mathrm{~A}, \mathrm{~B}, \mathrm{E}, \mathrm{F})}$
}

${ }^{1}$ Faculty of Health Sciences, University of Pécs, Hungary

Authors' contribution Wkład autorów:

A. Study design/planning zaplanowanie badań

B. Data collection/entry zebranie danych

C. Data analysis/statistics dane - analiza i statystyki D. Data interpretation interpretacja danych E. Preparation of manuscript przygotowanie artykułu F. Literature analysis/search wyszukiwanie i analiza literatury G. Funds collection zebranie funduszy

\section{Summary}

Background. EU efforts to exploit the positive social impact of sport have also been a priority in the Visegrad (V4) countries over the past decade. Our analysis aimed to compare the frequency of sports activities among the V4 countries' population and the effects of demographic, quality of life, sociocultural, socioeconomic, and sports infrastructural factors.

Material and methods. The data analyzed are from the Special Eurobarometer 472 Sport and Physical Activity survey, conducted in 2017. All respondents $(n=4,174)$ were over 15 years of age and resident in one of the four Visegrad countries. Frequency distribution, chi-square tests, and binary logistic regression models (including 12 explanatory variables and regular sports as independent variable) were used.

Results. Hungary had the highest rate $(16 \%)$ of respondents participating in sporting activity at least three times a week, while the Czech Republic had the highest rate of weekly regularity (31\%), and the lowest inactivity rate (42\%). In Poland, the inactivity rate was $62 \%$. Age, education, and social status had a significant effect on the frequency of sports in all four countries.

Conclusions. This paper highlights the slowly changeable role of demographic, sociocultural, and socioeconomic structures in influencing the frequency of sporting activity among the V4 countries, and underlines the potentially quick impact of sports infrastructure.

Keywords: sports, leisure activities, sociological factors, socioeconomic factors

\section{Streszczenie}

Wprowadzenie. Działania Unii Europejskiej mające na celu wykorzystanie pozytywnego wpływu sportu na społeczeństwo były również priorytetem w krajach Grupy Wyszehradzkiej (V4) w ostatniej dekadzie. Celem podjetej w niniejszej pracy analizy było porównanie częstotliwości aktywności sportowej wśród mieszkańców krajów Grupy Wyszehradzkiej oraz wpływu demografii, jakości życia, czynników społeczno-kulturowych, społecznoekonomicznych i infrasktrukturalnych.

Materiał i metody. Dane pochodzą z badania Eurobarometr 472 Sport i aktywność fizyczna, przeprowadzonego w $2017 \mathrm{r}$. Wszyscy respondenci $(\mathrm{n}=4174)$ to osoby w wieku od 15 . roku życia z krajów V4. W analizie zastosowano dystrybucję częstotliwości, test chi-kwadrat, binarne modele regresji logistycznej (obejmujące 12 zmiennych objaśniających oraz regularną aktywność sportową jako zmienną niezależną).

Wyniki. Największy odsetek (16\%) respondentów uprawiających sport przynajmniej trzy razy w tygodniu wykazano na Węgrzech. Czechy osiągnęły z kolei najwyższy współczynnik regularności w tygodniu (31\%) i najniższy współczynnik nieaktywności (42\%). W Polsce współczynnik nieaktywności wyniósł $62 \%$. Wiek, wykształcenie i status społeczny miały wpływ na częstotliwość uprawiania sportu we wszystkich czterech krajach.

Wnioski. W artykule podkreślono powoli zmieniajaca się rolę demografii oraz struktur społeczno-kulturowych i społeczno-ekonomicznych we wpływie na częstotliwość uprawiania sportu w krajach Grupy Wyszehradzkiej, a ponadto ujawniono możliwość szybkiego wpływu infrastruktury sportowej.

Słowa kluczowe: sport,zajęcia rekreacyjne, czynniki socjologiczne, czynniki socjoekonomiczne 


\section{Introduction}

The future of a nation is highly affected by the health status of the society, which is closely correlated with a physically active lifestyle [1]. Health improvements are also possible through physical activity and sport participation at an individual level, or through national policies [2]. Every investment into health promotion and sports participation, especially recreational activities, can also yield notable economic benefits [1-6].

The World Health Organization (WHO) considers physical inactivity as a noncommunicable factor for disease and mortality. WHO also recognizes that the conditions in which people live, and their lifestyles (including physical activity, amongst others), influence their health and quality of life. The main aim of the Global Action Plan [7] is to reduce inactivity rate by $10 \%$ in European countries by 2025 [8]. The WHO proposes 150 minutes or more of moderate to vigorous or 75 minutes vigorous physical activity each week for a healthy adult; however, it is suggested that adolescents engage in 60 minutes of moderate to vigorous intensity physical activity daily [7].

The inactivity rate among the European population in 2013 was 28.6\% [9]; in our study, we highlighted the Visegrad (V4) countries, comprising the Czech Republic, Hungary, Poland, and Slovakia. Similarities and differences can be found among the V4 countries: the main parallels can be found in their regional and cultural history, in particular their common socialist past. After 1990, these countries adopted different policies surrounding sport and health-enhancing physical activity [10]. The political and economic changes in 1989-1990 affected all social subsystems. Between 1990 and 2004 all governments supported elite sport, while leisure sport and recreational activity did not receive considerable attention [11]. However, the success of leisure sports associations and sports clubs depends on the governments' efforts, which are also positively associated with sport participation [11-14].

Hovemann and Wicker have examined the factors influencing the willingness to participate in sports; using logistic regression, they analyzed data from the 2004 Eurobarometer data at both EU and individual country level [15]. Bartolj and Slabe-Erker performed similar analyses, examining leisure time and physical activity of a sample of 22,771 European residents in 2007. They used a logit model, paying particular attention to the European transition countries including the V4 countries, which changed their economic system from socialism to capitalism in the early 90s [16].

Continuing the analysis of the Eurobarometer data [17-19], our study aims to compare the frequency of sports activity of those aged 15 and older in the V4 countries in a descriptive way, and to analyze the effects of demographic, quality of life, sociocultural, socioeconomic, and sports infrastructure factors on this.

\section{Material and methods}

\section{Methods of data collection}

The frequency of sports activity of the population in the V4 countries was researched in 2017 as a crosssectional study; data from the Special Eurobarometer 472 - Sport and Physical Activity survey ordered by the European Commission in 2017 was used [20]. This survey contained a total of 28,031 interviews, including 4,147 (female: 2,403; male: 1,744) respondents from the V4 countries' subsample (Czech Republic n=1,023; Hungary $n=1,038$; Poland n=997; Slovakia $n=1,089$ ) (Table 1). Respondents were selected using a multi-stage stratified systematic sampling; the sample represented the population aged 15 and older in the V4 countries, taking into consideration gender, age and type of settlement (rural area or village, small/middle town, large town). Data were collected in face-to-face questionnaire interviews, conducted in the native language of the respondents.

\section{Statistical analysis}

The database's information was analyzed using descriptive statistical methods. Differences between countries were represented by distribution ratios, with the extent measured using Pearson's chi-square test.

In addition to the categories formulated in the database, we created two further cumulative categories in order to interpret the frequency of sports activities. The first cumulated binary category of respondents engaging in regular sports activities was identified with people who do sports at least three times a week (1: people who do sports at least three times a week; 0: people who do sports less than three times a week). This category was obtained by combining the original Eurobarometer response categories 'at least 5 times a week' and '3-4 times a week'. This frequency is closest to the minimum amount of exercise optimally expected for complex physical health improvement, which is quoted by professionals as a total of 150 minutes of sports activities, 3 times a week [7]. Our second cumulative binary category included people engaging in sports activities at least once 
a week (1: people who do sports at least one time a week; 0: people who do sports less than one time a week), which we have obtained by combining categories 'at least 3 times a week' and '1-2 times a week'. We considered it important to create this second category as, although engaging in sports weekly is not clearly enough to influence physical health positively, it has been shown to have a positive effect on mental health [21] and quality of life [22]. The members of this group demonstrated significantly greater intentions towards sports, which could also be clearly identified in improving sports consumption habits [23]. Hovemann and Wicker also used this second category in their analysis of the 2004 Eurobarometer data [15], while Van Tuyckom and Scheerder [24] and Downward et al. [25] have used the binary category of completely inactive in sports (0) and their counterparts (1) based on the 2005 and 2009 Eurobarometer databases; their categories contained respondents who engage in sports activity even rarer than weekly. This is insufficient regarding health behavior, so we did not choose this approach. Information on the frequency of sports activity was self-reported.

We used chi-square tests and binary logistic regression analysis to check the factors influencing the frequency of sports among the population in the V4 countries. Doing regular sports activities ('minimum one time a week') has been examined as dependent variable and 12 demographic, sociocultural, socioeconomic, quality of life, and sports infrastructure factors were included as independent variables. Although sport can improve health status, this variable was considered inversely as an influencing factor in this study, which could also determine the frequency of sports. The respondents also mentioned poor quality of life as a barrier to participating in sports. The significance level was $\mathrm{p}<0.05$.

\section{Characteristics of the sample}

The basic characteristics of the sample representing the V4 countries - included in our analysis - are shown in Table 1. Examining the demographic characteristics of the sample, it was observed in all countries that women aged 25-49 and 50-64 years, are in the majority. In the case of age, it should be emphasized that the proportion of people over the age of 65 reaches $20 \%$ in all countries.

In terms of quality of life characteristics, in all four countries, almost two-thirds of respondents rate their health status positively. It is worth noting that members of the Polish sample consider their health status to be positive in the highest proportion (72.6\%), when compared to the V4 nations, and they are satisfied with the development of their lives. The members of the Hungarian sample are the least satisfied with their lives out of the four countries.

Among the sociocultural factors, by educational level, those with secondary education are in the majority in the V4 countries. In the case of the Polish and Hungarian samples, the proportion of those with a university degree, but also those with only a primary education, is the highest. In the case of the Polish sample, the proportion of those living in a village and those living with a partner is the highest, while the proportion of those who are divorced and living alone is the lowest. More than half of the Czech respondents live in small towns and have the highest divorce rates in the 4 countries.

In terms of socioeconomic characteristics, it should be noted that the members of the Czech sample selfreported their income and living environment the highest, with the greatest proportions of self-employed and other white collars, and the lowest proportion of manual workers and the unemployed. The proportion of those with high social status is the highest among members of the Slovak sample, although they reported their income situation and the status of their living environment the most unfavorable.

The sporting opportunities in their settlement are mostly viewed positively in each country. Of the four countries, the Czech respondents clearly rate their sports opportunities the most favorable.

Table 1. The basic characteristics of the sample representing the V4 countries [20]

\begin{tabular}{|c|c|c|c|c|c|}
\hline \multirow[t]{2}{*}{ Variable } & \multirow[t]{2}{*}{ Categories of the Variable } & $\begin{array}{c}\text { Czech } \\
\text { Republic }\end{array}$ & Hungary & Poland & Slovakia \\
\hline & & $n=1023$ & $n=1038$ & $\mathrm{n}=997$ & $n=1089$ \\
\hline \multicolumn{2}{|c|}{ Gender (D) } & $\mathbf{C Z}$ & HUN & POL & SVK \\
\hline & female & $57.30 \%$ & $58.70 \%$ & $59.50 \%$ & $56.50 \%$ \\
\hline & male & $42.70 \%$ & $41.30 \%$ & $40.50 \%$ & $43.50 \%$ \\
\hline \multicolumn{2}{|c|}{ Age (D) } & $\mathbf{C Z}$ & HUN & POL & SVK \\
\hline \multirow{4}{*}{ How old are you? } & $15-24$ years & $7.00 \%$ & $5.60 \%$ & $8.30 \%$ & $7.40 \%$ \\
\hline & 25-49 years & $43.30 \%$ & $39.20 \%$ & $42.20 \%$ & $40.20 \%$ \\
\hline & 50-64 years & $29.60 \%$ & $27.60 \%$ & $25.70 \%$ & $29.80 \%$ \\
\hline & 65 years and older & $20.00 \%$ & $27.60 \%$ & $23.80 \%$ & $22.60 \%$ \\
\hline
\end{tabular}




\begin{tabular}{|c|c|c|c|c|c|}
\hline \multicolumn{2}{|c|}{ Health status (Q) } & $\mathbf{C Z}$ & HUN & POL & SVK \\
\hline \multirow{5}{*}{ I am in good health } & strongly agree & $17.30 \%$ & $23.20 \%$ & $24.40 \%$ & $16.50 \%$ \\
\hline & agree & $49.10 \%$ & $39.80 \%$ & $48.20 \%$ & $46.40 \%$ \\
\hline & neither agree nor disagree & $21.00 \%$ & $20.90 \%$ & $10.00 \%$ & $23.50 \%$ \\
\hline & disagree & $10.50 \%$ & $11.80 \%$ & $14.60 \%$ & $11.50 \%$ \\
\hline & strongly disagree & $2.20 \%$ & $4.20 \%$ & $2.80 \%$ & $2.10 \%$ \\
\hline \multicolumn{2}{|c|}{ Life satisfaction (Q) } & $\mathbf{C Z}$ & HUN & POL & SVK \\
\hline \multirow{4}{*}{$\begin{array}{c}\text { On the whole, how satisfied or } \\
\text { not are you with the life you lead? } \\
\text { Are you...? }\end{array}$} & very satisfied & $14.50 \%$ & $8.10 \%$ & $10.50 \%$ & $13.80 \%$ \\
\hline & fairly satisfied & $72.00 \%$ & $67.00 \%$ & $77.10 \%$ & $66.30 \%$ \\
\hline & not very satisfied & $12.50 \%$ & $21.00 \%$ & $10.70 \%$ & $16.50 \%$ \\
\hline & not at all satisfied & $1.00 \%$ & $3.90 \%$ & $1.70 \%$ & $3.40 \%$ \\
\hline \multicolumn{2}{|c|}{ Educational level (SC) } & $\mathbf{C Z}$ & HUN & POL & SVK \\
\hline \multirow{4}{*}{$\begin{array}{l}\text { What is the highest level of } \\
\text { education that has been achieved } \\
\text { by you? }\end{array}$} & not completed/primary & $11.10 \%$ & $22.10 \%$ & $20.50 \%$ & $16.70 \%$ \\
\hline & completed secondary & $70.40 \%$ & $51.00 \%$ & $54.10 \%$ & $63.70 \%$ \\
\hline & $\begin{array}{c}\text { completed bachelor level or } \\
\text { equivalent }\end{array}$ & $10.30 \%$ & $18.50 \%$ & $7.90 \%$ & $8.70 \%$ \\
\hline & $\begin{array}{l}\text { completed master, doctoral } \\
\text { degree }\end{array}$ & $8.30 \%$ & $8.40 \%$ & $17.50 \%$ & $10.90 \%$ \\
\hline \multicolumn{2}{|c|}{ Type of community (SC) } & $\mathbf{C Z}$ & HUN & POL & SVK \\
\hline \multirow{3}{*}{ Would you say you live in a...? } & rural area or village & $20.00 \%$ & $15.60 \%$ & $44.90 \%$ & $39.50 \%$ \\
\hline & small/medium town & $53.40 \%$ & $50.20 \%$ & $25.70 \%$ & $43.30 \%$ \\
\hline & large town & $26.60 \%$ & $34.20 \%$ & $29.40 \%$ & $17.20 \%$ \\
\hline \multicolumn{2}{|c|}{ Marital status (SC) } & CZ & HUN & POL & SVK \\
\hline \multirow{4}{*}{$\begin{array}{l}\text { Which of the following best } \\
\text { corresponds to your own current } \\
\text { situation? }\end{array}$} & married/single with partner & $62.00 \%$ & $63.20 \%$ & $72.50 \%$ & $67.50 \%$ \\
\hline & divorced or separated & $16.30 \%$ & $10.30 \%$ & $5.50 \%$ & $6.50 \%$ \\
\hline & widowed & $9.20 \%$ & $15.90 \%$ & $12.00 \%$ & $12.90 \%$ \\
\hline & single & $12.60 \%$ & $10.40 \%$ & $10.00 \%$ & $13.10 \%$ \\
\hline \multicolumn{2}{|c|}{ Income situation of the household (SE) } & $\mathbf{C Z}$ & HUN & POL & SVK \\
\hline \multirow{5}{*}{$\begin{array}{l}\text { Taking all these income sources } \\
\text { by individuals in your household } \\
\text { together, after tax, which } \\
\text { category corresponds to your } \\
\text { annual household income? }\end{array}$} & lower quintile & $23.10 \%$ & $22.60 \%$ & $30.90 \%$ & $34.50 \%$ \\
\hline & 2nd quintile & $29.50 \%$ & $33.60 \%$ & $27.90 \%$ & $24.90 \%$ \\
\hline & 3rd quintile & $23.60 \%$ & $20.70 \%$ & $21.30 \%$ & $21.60 \%$ \\
\hline & 4th quintile & $16.90 \%$ & $14.60 \%$ & $13.00 \%$ & $10.80 \%$ \\
\hline & upper quintile & $6.90 \%$ & $8.40 \%$ & $6.90 \%$ & $8.30 \%$ \\
\hline \multicolumn{2}{|c|}{ Social status (SE) } & $\mathbf{C Z}$ & HUN & POL & SVK \\
\hline \multirow{3}{*}{$\begin{array}{l}\text { Where would you place yourself } \\
\text { on this ladder relative to other } \\
\text { people in the own country? }\end{array}$} & top $(7-10)$ & $21.80 \%$ & $11.50 \%$ & $20.60 \%$ & $30.80 \%$ \\
\hline & middle (4-6) & $67.50 \%$ & $75.30 \%$ & $68.30 \%$ & $59.20 \%$ \\
\hline & bottom (1-3) & $10.70 \%$ & $13.20 \%$ & $11.00 \%$ & $10.00 \%$ \\
\hline \multicolumn{2}{|c|}{ Occupational status (SE) } & $\mathbf{C Z}$ & HUN & POL & SVK \\
\hline \multirow{8}{*}{ What is your current occupation? } & self-employed & $11.70 \%$ & $5.20 \%$ & $5.40 \%$ & $7.50 \%$ \\
\hline & managers & $10.00 \%$ & $5.90 \%$ & $10.70 \%$ & $6.60 \%$ \\
\hline & other white collars & $25.90 \%$ & $14.60 \%$ & $15.20 \%$ & $13.40 \%$ \\
\hline & manual workers & $15.40 \%$ & $30.30 \%$ & $23.50 \%$ & $28.70 \%$ \\
\hline & house persons & $4.20 \%$ & $1.90 \%$ & $6.10 \%$ & $3.00 \%$ \\
\hline & unemployed & $2.70 \%$ & $4.70 \%$ & $4.40 \%$ & $8.00 \%$ \\
\hline & retired & $25.80 \%$ & $35.30 \%$ & $30.30 \%$ & $28.80 \%$ \\
\hline & students & $4.20 \%$ & $2.10 \%$ & $4.30 \%$ & $3.90 \%$ \\
\hline \multicolumn{2}{|c|}{ Living environment status (SE) } & $\mathbf{C Z}$ & HUN & POL & SVK \\
\hline \multirow{5}{*}{$\begin{array}{l}\text { Generally speaking, would you } \\
\text { say that: your neighborhood is... }\end{array}$} & very poor & $1.00 \%$ & $2.10 \%$ & $1.20 \%$ & $9.50 \%$ \\
\hline & fairly poor & $7.80 \%$ & $16.00 \%$ & $13.20 \%$ & $21.40 \%$ \\
\hline & average & $76.90 \%$ & $76.40 \%$ & $74.70 \%$ & $57.10 \%$ \\
\hline & fairly rich & $13.90 \%$ & $5.40 \%$ & $10.50 \%$ & $11.30 \%$ \\
\hline & very rich & $0.40 \%$ & $0.10 \%$ & $0.40 \%$ & $0.70 \%$ \\
\hline \multicolumn{2}{|c|}{$\begin{array}{l}\text { Sports opportunities of the settlement } \\
\text { (many sport opportunities in area) (SI) }\end{array}$} & CZ & HUN & POL & SVK \\
\hline \multirow{2}{*}{$\begin{array}{l}\text { The area where you live offers } \\
\text { you many opportunities to be } \\
\text { physically active }\end{array}$} & agree & $73.60 \%$ & $63.60 \%$ & $66.50 \%$ & $61.30 \%$ \\
\hline & disagree & $26.40 \%$ & $36.40 \%$ & $33.50 \%$ & $38.70 \%$ \\
\hline
\end{tabular}

Notes: abbreviations of factors: D - demographic, Q - quality of life, SC - sociocultural, SI - socioeconomic, SI - sports infrastructure. 


\section{Results}

Figure 1 shows the frequency of sporting activity among the population of the V4 countries in 2017.

Of the Czech population, $12 \%$ participated in sporting activities at least three times a week, while almost a third (31\%) on a weekly basis; $27 \%$ participated occasionally, and $42 \%$ of them never took part.

In Hungary, 9\% of the population did sports activities almost every day, $16 \%$ at least 3 times a week, and $29 \%$ did at least once a week; more than half (57\%) never participated in sports, while a further $14 \%$ of them only did so occasionally.

Of the Polish respondents, $11 \%$ participated in sporting activities at least three times a week, while almost a quarter of them (24\%) did soon a weekly basis; the inactivity rate was $62 \%$.

A proportion of $11 \%$ of the Slovak population engaged in sports at least 3 times a week, more than a quarter $(27 \%)$ at least once a week, while a further $22 \%$ did so only occasionally; more than half of the respondents (54\%) were inactive in sports in this year.

The average characteristics of the other 24 countries in the European Union are presented for the aim of comparison. In these countries, $8 \%$ of the 15 years and older population participated in sports almost daily, with a further $20 \%$ at least 3 times a week; a total of $39 \%$ of them did sports on a weekly basis, while $46 \%$ stayed away from sports entirely.

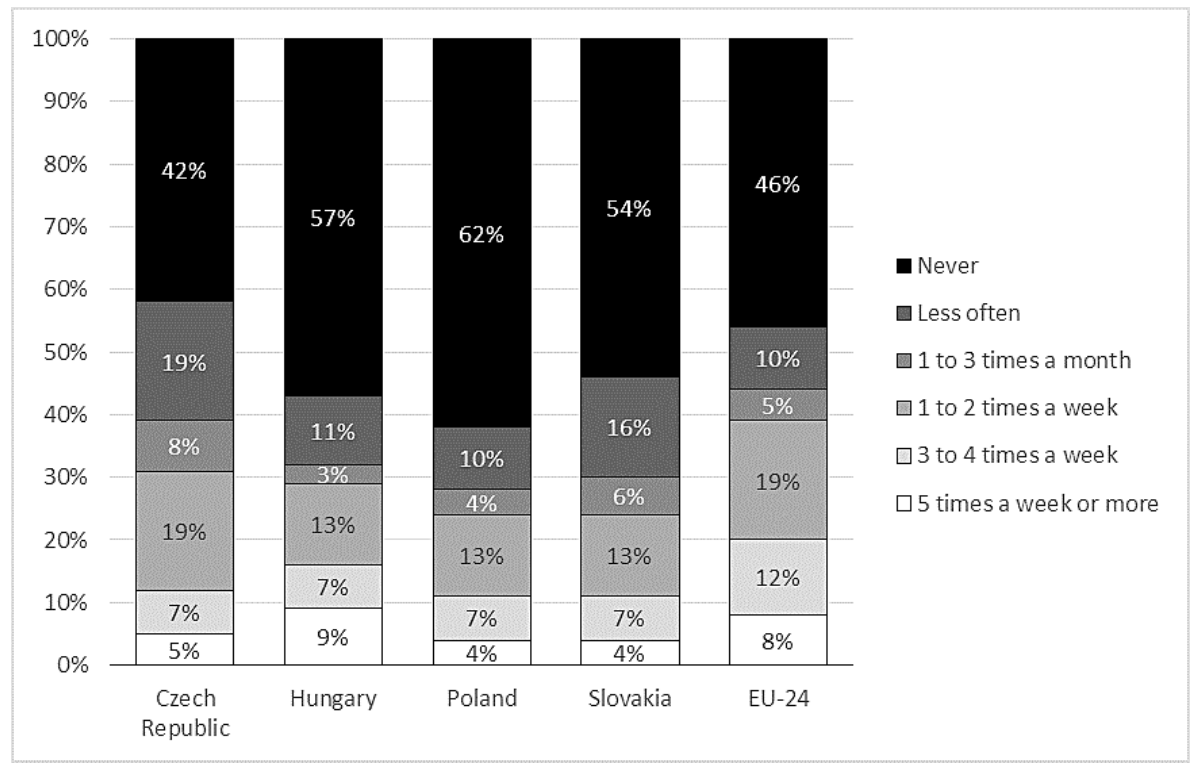

Figure 1. Frequency of sports in the V4 countries and the EU-24 countries in 2017 (\%) Source: own edition based on Special Eurobarometer 472 [20].

Comparing the V4 countries (Table 2), it can be stated that the proportion of respondents 'engaging in sports activities at least 3 times a week' - which is a priority treated category due to recreation and improvement of health - was highest in Hungary. This favorable indicator was caused mainly by a significantly higher proportion of respondents 'engaging in sports activities at least 5 times a week' compared to the other countries $(\mathrm{p}<0.001$ for all other V4 countries). The proportion of people 'engaging in sports activities at least once a week' was highest in the Czech Republic (31\%) and Hungary (29\%), which was significantly higher in both countries compared to Slovakia and Poland. The 'never doing sports' (the most unfavorable category for health recreation and sport) group was significantly smaller in the Czech Republic compared to all other V4 countries $(42 \%, \mathrm{p}<0.05$ in all cases). The opposite was true of the Polish respondents, with two-thirds of them (62\%) never participating in sports; this was significantly greater than in any of the four countries $(\mathrm{p}<0.05$ compared to all other countries). A significant difference could not be found in the proportion of inactive people between Slovakia (54\%) and Hungary (57\%), which were significantly higher than in the Czech Republic and significantly lower than in Poland.

Regarding the frequencies of sports in the V4 countries compared to other EU countries in 2017, it is difficult to find any categories in which they approach the average rates of the remaining 24 EU countries. The two positive exceptions were (1) the proportion of 'never doing sports' in the Czech Republic (42\%) was significantly lower than the EU-24 average, and (2) the proportion of respondents 'engaging in sports activities at least 5 
times a week' in Hungary (9\%) which is not significantly different $\left(\chi^{2}=0.506, p=0.462\right)$ from the other EU-24 countries' (8\%) average rate (Figure 1).

Table 2. Differences in sports frequency (minimum 3 times a week, minimum 1 time a week, never) between V4 countries in 2017

\begin{tabular}{|c|c|c|c|c|c|c|c|}
\hline \multirow{2}{*}{\multicolumn{2}{|c|}{ Countries }} & \multicolumn{2}{|c|}{ Minimum 3 times a week } & \multicolumn{2}{|c|}{ Minimum 1 time a week } & \multicolumn{2}{|c|}{ Never } \\
\hline & & $\begin{array}{c}\text { frequency } \\
\% \\
\end{array}$ & $\begin{array}{l}\chi^{2} \text { test } \\
\text { p value }\end{array}$ & $\begin{array}{c}\text { frequency } \\
\% \\
\end{array}$ & $\begin{array}{c}\chi^{2} \text { test } \\
\text { p value }\end{array}$ & $\begin{array}{c}\text { frequency } \\
\% \\
\end{array}$ & $\frac{\chi^{2} \text { test }}{\text { p value }}$ \\
\hline \multirow{2}{*}{ Hungary - Czech Republic } & HUN & $16 \%$ & \multirow{2}{*}{0.004} & $29 \%$ & \multirow{2}{*}{0.419} & $57 \%$ & \multirow{2}{*}{$<0.001$} \\
\hline & $\mathrm{CZ}$ & $12 \%$ & & $31 \%$ & & $42 \%$ & \\
\hline \multirow{2}{*}{ Hungary - Poland } & HUN & $16 \%$ & \multirow{2}{*}{0.001} & $29 \%$ & \multirow{2}{*}{0.014} & $57 \%$ & \multirow{2}{*}{0.047} \\
\hline & POL & $11 \%$ & & $24 \%$ & & $62 \%$ & \\
\hline \multirow{2}{*}{ Hungary - Slovakia } & HUN & $16 \%$ & \multirow{2}{*}{$<0.001$} & $29 \%$ & \multirow{2}{*}{0.005} & $57 \%$ & \multirow{2}{*}{0.149} \\
\hline & SL & $11 \%$ & & $24 \%$ & & $54 \%$ & \\
\hline \multirow{2}{*}{ Czech Republic-Poland } & $\mathrm{CZ}$ & $12 \%$ & \multirow{2}{*}{0.569} & $31 \%$ & \multirow{2}{*}{0.001} & $42 \%$ & \multirow{2}{*}{$<0.001$} \\
\hline & POL & $11 \%$ & & $24 \%$ & & $62 \%$ & \\
\hline \multirow{2}{*}{ Czech Republic - Slovakia } & $\mathrm{CZ}$ & $12 \%$ & \multirow{2}{*}{0.517} & $31 \%$ & \multirow{2}{*}{$<0.001$} & $42 \%$ & \multirow{2}{*}{$<0.001$} \\
\hline & SL & $11 \%$ & & $24 \%$ & & $54 \%$ & \\
\hline \multirow{2}{*}{ Poland - Slovakia } & POL & $11 \%$ & \multirow{2}{*}{0.948} & $24 \%$ & \multirow{2}{*}{0.787} & $62 \%$ & \multirow{2}{*}{0.001} \\
\hline & SL & $11 \%$ & & $24 \%$ & & $54 \%$ & \\
\hline Slovakia - FU24 & SL & $11 \%$ & 0000 & $24 \%$ & 0000 & $54 \%$ & 0000 \\
\hline Slovakıa - EUZ4 & EU24 & $20 \%$ & 0.000 & $39 \%$ & 0.000 & $46 \%$ & 0.000 \\
\hline Hungary_FU24 & HUN & $16 \%$ & $0 \cap 01$ & $29 \%$ & $\leq 0 \Omega 01$ & $57 \%$ & $-0 \Omega 01$ \\
\hline Hungary - EUZ4 & EU24 & $20 \%$ & 0.001 & $39 \%$ & $<0.001$ & $46 \%$ & $<0.001$ \\
\hline Dolond FU24 & POL & $11 \%$ & $-0 \Omega 01$ & $24 \%$ & $-0 \Omega 01$ & $62 \%$ & - 0001 \\
\hline Poland - EUZ4 & EU24 & $20 \%$ & $<0.001$ & $39 \%$ & $<0.001$ & $46 \%$ & $<0.001$ \\
\hline Croch Ponublic EU24 & $\mathrm{CZ}$ & $12 \%$ & $-0 \Omega 01$ & $31 \%$ & & $42 \%$ & 0017 \\
\hline Czecn Kepublic - EUZ4 & EU24 & $20 \%$ & $<0.001$ & $39 \%$ & $<0.001$ & $46 \%$ & 0.011 \\
\hline
\end{tabular}

Our intention was to examine the demographic, quality of life, sociocultural, socioeconomic, and sports infrastructural factors influencing the frequency of sports among the population of the Visegrad countries for 2017; we did so using binary logistic regression analysis. We included 12 factors in our study. Firstly, we examined whether the single variables have significant correlation with the frequency of sports. For the second step, we have analyzed whether they have an independent influencing effect by controlling the effect of other factors.

A significant relationship was found for all the involved factors' relationship with the variable of regular sports, except the variables of gender and living environment status, when chi-square tests were performed (Table 3). No significant difference was found between the Visegrad countries regarding gender characteristics of sports activities, while living environment status was not significant among the Czech and Slovak population. Higher frequency of sports activities was present among: younger age groups; those with better health and quality of life; groups with higher educational level; people living alone; those with better socioeconomic and occupational status; respondents with higher satisfaction with sports opportunities. We also wished to further refine these trends by analyzing these variables' odds ratios using binary logistic regression (Table 3).

Table 3. Correlations of factors influencing regular sports activities ('minimum one time a week') in the V4 countries (chisquare tests and binary logistic regression models significance values)

\begin{tabular}{|c|c|c|c|c|c|c|c|c|}
\hline \multirow{2}{*}{ Factors } & \multicolumn{2}{|c|}{ Czech Republic } & \multicolumn{2}{|c|}{ Hungary } & \multicolumn{2}{|c|}{ Poland } & \multicolumn{2}{|c|}{ Slovakia } \\
\hline & Chi-sq. & Reg. & Chi-sq. & Reg. & Chi-sq. & Reg. & Chi-sq. & Reg. \\
\hline \multicolumn{9}{|l|}{ Demographic factors: } \\
\hline gender & 0.920 & 0.751 & 0.658 & 0.790 & 0.710 & 0.047 & 0.844 & 0.970 \\
\hline age & $<0.001$ & $<0.001$ & $<0.001$ & $<0.001$ & $<0.001$ & $<0.001$ & $<0.001$ & 0.005 \\
\hline \multicolumn{9}{|l|}{ Quality of life factors: } \\
\hline health status (self-reported) & $<0.001$ & 0.124 & $<0.001$ & 0.676 & $<0.001$ & 0.181 & $<0.001$ & 0.682 \\
\hline life satisfaction (self-reported) & $<0.001$ & 0.079 & $<0.001$ & 0.217 & $<0.001$ & 0.438 & $<0.001$ & 0.160 \\
\hline
\end{tabular}




\begin{tabular}{|c|c|c|c|c|c|c|c|c|}
\hline \multicolumn{9}{|l|}{ Sociocultural factors: } \\
\hline educational level & $<0.001$ & 0.005 & $<0.001$ & 0.003 & $<0.001$ & $<0.001$ & $<0.001$ & 0.001 \\
\hline type of community & 0.037 & 0.227 & 0.036 & 0.961 & 0.009 & 0.007 & 0.001 & $<0.001$ \\
\hline marital status & $<0.001$ & 0.297 & 0.001 & 0.006 & $<0.001$ & 0.511 & $<0.001$ & 0.003 \\
\hline \multicolumn{9}{|l|}{ Socioeconomic factors: } \\
\hline income situation of the household & $<0.001$ & 0.051 & $<0.001$ & 0.001 & $<0.001$ & 0.189 & $<0.001$ & 0.746 \\
\hline social status & $<0.001$ & 0.018 & $<0.001$ & 0.001 & $<0.001$ & $<0.001$ & $<0.001$ & 0.017 \\
\hline occupational status & $<0.001$ & 0.126 & $<0.001$ & 0.150 & $<0.001$ & 0.410 & $<0.001$ & 0.002 \\
\hline living environment status & 0.979 & 0.974 & $<0.001$ & 0.069 & 0.027 & 0.884 & 0.269 & 0.563 \\
\hline \multicolumn{9}{|l|}{ Sport infrastructural factor: } \\
\hline $\begin{array}{c}\text { sports opportunities of the } \\
\text { settlement (based on subjective } \\
\text { evaluation) }\end{array}$ & 0.014 & 0.412 & $<0.001$ & 0.027 & $<0.001$ & 0.027 & $<0.001$ & 0.003 \\
\hline \multirow{3}{*}{$\begin{array}{l}\text { Values of binary logistic } \\
\text { regression models }\end{array}$} & $\chi^{2}$ & 72.0 & $\chi^{2}$ & 118.3 & $\chi^{2}$ & 127.3 & $\chi^{2}$ & 182.1 \\
\hline & Sig. & $<0.001$ & Sig. & $<0.001$ & Sig. & $<0.001$ & Sig. & $<0.001$ \\
\hline & Nag. $R^{2}$ & 0.112 & Nag. $R^{2}$ & 0.206 & Nag. $R^{2}$ & 0.282 & Nag. $R^{2}$ & 0.315 \\
\hline
\end{tabular}

Notes: Factors being significant only by the chi-square tests are in italics. Factors being significant only by the regression models are in bold. Factors being significant by both statistical procedures are in bold and italics too.

Table 3 shows that the single binary logistic regression models for the countries became significant with an explanatory power ranging from $11.2 \%$ to $31.5 \%$ (Nagelkerke $\mathrm{R}^{2}$ ). It can be seen that three factors in the case of Czech Republic, six factors in the case of Poland and Hungary, and seven factors in the case of Slovakia, had an independent effect on weekly sports activities.

When examining the factors one by one using regression models (Table 4), age, educational status, and social status were significant factors in all four countries. The two youngest age groups (under 18 and between 18-24 years) had the highest odds ratios while the oldest age groups (between 50-64 years and 65 years and older) had the lowest. The impact of educational level was similar in all four countries, with the highest odds ratios among bachelor, master, or doctoral degree groups, while those with primary or without completed primary educational level had the lowest. It can be seen that the most favorable social status produces the highest proportion of regular sports activity. Respondents belonging to the lower status group had the worst position in each country. The odds ratio between the two categories was at least 2.5 times higher among the Czech, Hungarian and Polish population, while the difference for Slovakia was 66\%. The factor of satisfaction with sports opportunities of the settlement (the area where the respondents live) should also be emphasized, which significantly influenced the frequency of sports activities among the Hungarian, Polish, and Slovak population.

Table 4. Odds ratios of the factors influencing regular sports activities of the V4 countries based on the binary logistic regression model

\begin{tabular}{|c|c|c|c|c|c|}
\hline \multirow{2}{*}{ Variable } & \multirow{2}{*}{ Categories of the Variable } & Czech Rep. & Hungary & Poland & Slovakia \\
\hline & & $\operatorname{Exp}(B)$ & $\operatorname{Exp}(B)$ & $\operatorname{Exp}(B)$ & $\operatorname{Exp}(B)$ \\
\hline \multicolumn{2}{|c|}{ Gender } & $\mathbf{C Z}$ & HUN & POL & SVK \\
\hline Reference: female & male & & & 1.546 & \\
\hline \multicolumn{2}{|c|}{ Age } & $\mathbf{C Z}$ & HUN & POL & SVK \\
\hline \multirow{3}{*}{ Reference: 65 years and older } & 15-24 years & 4.444 & 5.760 & 13.314 & 0.845 \\
\hline & $25-49$ years & 3.055 & 1.988 & 2.356 & 1.523 \\
\hline & 50-64 years & 1.459 & 1.082 & 1.291 & 0.603 \\
\hline \multicolumn{2}{|c|}{$\begin{array}{c}\text { Sports opportunities of the settlement (many sport } \\
\text { opportunities in area) }\end{array}$} & $\mathrm{CZ}$ & HUN & POL & SVK \\
\hline Reference: disagree & agree & & 1.514 & 1.791 & 2.009 \\
\hline \multicolumn{2}{|c|}{ Educational level } & $\mathbf{C Z}$ & HUN & POL & SVK \\
\hline \multirow{3}{*}{$\begin{array}{l}\text { Reference: not completed/ } \\
\text { completed primary }\end{array}$} & completed secondary & 1.355 & 1.218 & 2.094 & 1.198 \\
\hline & $\begin{array}{c}\text { completed bachelor level or } \\
\text { equivalent }\end{array}$ & 2.493 & 1.822 & 1.357 & 2.909 \\
\hline & $\begin{array}{l}\text { completed master, doctoral } \\
\text { degree }\end{array}$ & 2.550 & 3.637 & 5.462 & 3.133 \\
\hline
\end{tabular}




\begin{tabular}{|c|c|c|c|c|c|}
\hline \multicolumn{2}{|c|}{ Marital status } & $\mathbf{C Z}$ & HUN & POL & SVK \\
\hline \multirow{3}{*}{$\begin{array}{l}\text { Reference: unmarried } \\
\text { (without partner) }\end{array}$} & married/single with partner & & 0.468 & & 0.308 \\
\hline & divorced or separated & & 0.561 & & 0.571 \\
\hline & widowed & & 1.157 & & 0.204 \\
\hline \multicolumn{2}{|c|}{ Type of community } & $\mathbf{C Z}$ & HUN & POL & SVK \\
\hline \multirow{2}{*}{ Reference: rural area or village } & small/medium town & & & 2.329 & 1.482 \\
\hline & large town & & & 1.381 & 0.408 \\
\hline \multicolumn{2}{|c|}{ Social status } & $\mathbf{C Z}$ & HUN & POL & SVK \\
\hline \multirow{2}{*}{ Reference: bottom } & middle & 2.173 & 2.256 & 2.391 & 0.921 \\
\hline & top & 2.611 & 4.464 & 5.992 & 1.667 \\
\hline \multicolumn{2}{|c|}{ Occupational status } & $\mathbf{C Z}$ & HUN & POL & SVK \\
\hline \multirow{7}{*}{ Reference: self-employed } & managers & & & & 0.668 \\
\hline & other white collars & & & & 0.447 \\
\hline & manual workers & & & & 0.391 \\
\hline & house persons & & & & 0.542 \\
\hline & unemployed & & & & 0.241 \\
\hline & retired & & & & 0.313 \\
\hline & students & & & & 3.904 \\
\hline \multicolumn{2}{|c|}{ Income situation of the household } & $\mathbf{C Z}$ & HUN & POL & SVK \\
\hline \multirow{4}{*}{ Reference: upper quintile } & lower quintile & & 0.535 & & \\
\hline & 2nd quintile & & 0.310 & & \\
\hline & 3rd quintile & & 0.477 & & \\
\hline & 4th quintile & & 0.902 & & \\
\hline
\end{tabular}

Notes: Factors being significant $(\mathrm{p}<0.05)$ are in bold and italic.

The odds ratio of regular sports activity by respondents living in an environment with good sports opportunities was 50\% higher among the Hungarian population, 79\% higher among the Polish population, and more than twice as much of the Slovak population compared to the group of respondents without it.

The marital status and type of settlement had an independent effect on the frequency of regular sports activity in two countries. Regarding marital status, respondents living in families had more than two times less chance to participate in sports in Hungary, and more than three times less chance in Slovakia, than singles (who were considered the most athletic group). Considering type of settlement, this was significant for the Polish and Slovak population. In both countries the population of small and medium-sized cities had a significantly higher chance of doing regular sport (48\% in Slovakia and $230 \%$ in Poland) than the population of the reference category (a rural area or village).

Gender is also an independent influencing factor, but only in the case of the Polish population: Polish men are $55 \%$ more likely to do regular sports than Polish women.

The income situation of the household was an independent factor among the Hungarian population only. It can be said that the members of the quintile with the most favorable income situation had a 3 times better chance to partake in regular sports than the members of the group $2^{\text {nd }}$ quintile. This group's members have a two times better chance to do regular sports than those of the third quintile.

The frequency of sports among the Slovak population was also influenced by occupational status. The highest odds ratio was among students, followed by self-employed respondents. The two least athletic groups were the unemployed and manual workers with the lowest odds ratios.

The Czech Republic, characterized by the most favorable frequency of sports, differed from the causal pattern of the other three countries based on the examination of countries separately. Only age, educational level, and social status had an independent influence on the Czech population. The sports opportunities of the environment and socioeconomic factors were also highlighted in the other three countries (two factors in Hungary and Poland, and three factors in Slovakia). The quality of life factors showed no independent influencing effect in any of the V4 countries. 


\section{Discussion}

The V4 countries showed a heterogenous picture in terms of improving the frequency of sports, similar to the general situation in the EU. It can be said that the frequency of sports activities in the Czech Republic and Hungary was far more positive than that of the other two countries.

However, heterogenous results could be found in the literature. The WHO Physical Activity Factsheet reported on the differences of the estimated prevalence of sufficient physical activity level among the V4 countries. Large differences were found in the four countries among adults: the Czech Republic with 66\%, Slovakia with 12\%, Poland with 88\%, and Hungary with 31\% [26]. These facts indicated the need for a European Physical Activity Monitoring System to get authentic and accurate data, like the Eurobarometer survey, using objective measurement also in data collection about physical activity [27].

Contrary to our study, only $28 \%$ of the population reported participation in sports once a week or more in the Czech Republic, ranking lowest among the countries investigated by Ruetten et al. Conducting a study using the Eurobarometer 2009 data and qualitative interviews, they discovered that inactivity could be as a result of the lack of necessary infrastructure designed for leisure time physical activity). Promotion of voluntary sports organizations, as well as of leisure time physical activity, could be key elements of a successful transition in the following years [28].

Based on the results of Hovemann and Wicker, it can be stated that there may be more influencing factors for the entire EU population than for the individual member states [15]; they examined the factors influencing the willingness to do sports by logistic regression, based on 2004 Eurobarometer data. A negative relationship was found between willingness to do sports and age in all V4 countries; no further influencing factors could were identified in Hungary. Women's lower willingness to do sports has also been shown in the Czech Republic and Poland, with years spent in educational system having a positive effect in the Czech Republic. Being married is a negative factor for Poles and Slovaks, and the increase in settlement size improves the willingness to do sports in both countries. Interestingly, respondents with an immigrant background have showed a higher willingness to do sports than natives in Poland.

Bartolj and Slabe-Erker used a logit model to examine leisure time physical activity of European residents on a sample of 22,771 people in 2007, with particular attention paid to the European transition countries (which also includes V4 countries). Age and number of children living in the household was shown to have a negative effect on physical activity. Women, respondents with higher incomes, part-time employment, less active social life, higher educational level, and better social and health status had more willingness to be physically active [16].

In our study, the data showed that the Polish population's frequency of sport is the most unfavorable, from which the indicators of Slovakia differ only minimally. The Slovak trend towards a decline in the frequency of sports activities appears to be particularly unfavorable.

The tendency looks like that the willingness to do sports decreases with age, with the exception of the odds ratios in Slovakia; this is also consistent with the results of both Bartolj and Slabe-Erker [16] and Hovemann and Wicker [15]. Higher level in education has a positive effect on sports willingness in all countries, which was confirmed by Bartolj and Slabe-Erker, but only in the Czech Republic by Hovemann and Wicker.

Buck et al. highlighted the importance of socioeconomic parameters, such as educational level, gender, and social class. However, among older adults, the built environment was also significantly associated with sedentary behavior [29]. Lakerveld et al. examined, using a CHAID algorithm, the relative importance of sociodemographic correlates of sedentary time based on the data of 26,617 adults from the 2013 Special Eurobarometer 412 , and described a clear sociodemographic profile: predictors of extensive sitting were higher education, whitecollar jobs, higher socioeconomic status, and frequent internet use; $73.5 \%$ of the Czech, $80.1 \%$ of Slovak, $88.2 \%$ Hungarian, and $90.0 \%$ of the Polish population reported more than 7.5 hours/day sitting [30].

Gender differences were found in our study only in Poland, which echoes the results of Hovemann and Wicker [15], but contradicts the results of Bartolj and Slabe-Erker [16]. However, this last finding is valid for the whole block of Central and Eastern European nations, and not for specific countries.

Mayo and colleagues in 2019 examined the physical activity levels reported by the International Physical Activity Questionnaire of 53,607 adults using Eurobarometer 2013 and 2017 data. The physical inactivity prevalence showed an increase across the EU for both women and men between 2013 and 2017, but women's inactivity rate was lower versus men. The prevalence was reduced only in Belgium's women and Luxembourg's men. Based on their results, the study suggested that physical activity monitoring and intervention planning take a gender-sensible approach [8]. 
The positive effect of single marital status on the willingness to do sports appeared in both Hungary and Slovakia - this is also the same trend indicated by Hovemann and Wicker [15], and indirectly by Bartolj and Slabe-Erker [16].

The clearly positive effect of the increasing settlement size [15] is only partially reflected in our results in Poland, and mixed effects in Slovakia. However, the presence of swimming pools and recreational parks is especially typical for bigger settlements, which have a highlighted boosting role for the population's sports activities [31].

The positive effect of a higher social situation was confirmed in all our models [16]. The positive effect of a greater income situation was found only in the case of Hungary, however an appropriate level of income is a requirement of participating in recreational sports activities [32].

Our models used several further influencing variables, and demonstrated their significant effects that the cited literature did not, or took a different approach and examined for the V4 countries. Such factors included the status of the employee, the provision of sports opportunities, or income situation.

\section{Limitations}

Even though publications included in the discussion section were published in 2019 , the data were collected much earlier $(2004,2007,2009,2013)$; as this is prior to the 2017 Eurobarometer survey, the situation of the V4 countries (especially infrastructure, income, and SES, environment, etc.) is not directly comparable, though it could serve as indirect context.

It must be mentioned that the applied cut-off-point for adults (doing sports activities at least three times a week) of our study is unable to cover the recommendation for adolescents exactly (which includes not only the recommended frequency, but the recommended time extent too [7]). It was not possible to get information about individual respondents' weekly time extent of sports activities, which resulted using only the frequencies of them.

\section{Conclusions}

The descriptive analysis highlighted that the frequency of sports in the population of the V4 countries showed a less favorable distribution in 2017 than the average values in other EU countries. The comparative analysis drew attention to the fact that demographic, sociocultural, and economic structures in the V4 countries also have a fundamental influence on the development of sports. Also, the analysis emphasized the impact of sports infrastructure, and sports supply in a broader sense, on the development of the frequency of sports in the population. This factor may also be of particular interest to policymakers, because the infrastructure and supply conditions of sport can be positively influenced with less effort in the shorter term, as opposed to the slow and difficult formation of large social structures.

\section{Disclosures and acknowledgements}

The publication costs were partially funded by the Human Resource Development Operational Program, grant No.: HRDOP-3.6.2-16-2017-00003, Cooperative Research Network in Economy of Sport, Recreation and Health. The authors declare that the study design; collection, management, analysis, and interpretation of data; writing of the manuscript are independent of Human Resource Development Operational Program. The authors declare that they have no competing interests.

\section{References:}

1. Faragó B, Szakály Z, Tóth ÁK, Konczos C, Kovács N, Pápai Z, et al. Development of sports nation on the way of health management. Int J Sport Health Sci. 2020; 14(2):78-84.

2. Lera-López F, Marco R. Sports participation, physical activity, and health in the European regions. J Sports Sci. 2018; 36(15): 1784-1791. https://doi.org/10.1080/02640414.2017.1418810

3. Rozpara M, Nowak E, Nawrocka A, Polechonski J, Debska M, Mynarski W. Evaluation of health benefits of peripheral resistance training based on energy expenditure in women aged 25-35 years. Health Prob Civil. 2019; 13(1): 30-37. https://doi.org/10.5114/hpc.2019.81107

4. Niznikowska E, Bergier J, Bergier B, Acs P, Junger J, Salonna F. Factors influencing level of physical activity among female students from the Visegrad countries. Health Prob Civil. 2019; 13(1): 19-29.

https://doi.org/10.5114/hpc.2018.80225 
5. Bergier J, Tsos A, Popovych D, Bergier B, Niźnikowska E, Ács P, et al. Level of and factors determining physical activity in students in Ukraine and the Visegrad countries. Int J Environ Res Public Health. 2018; 15(8): 1738. https://doi.org/10.3390/ijerph15081738

6. Stocker M. [The role of dematerialization in value creation]. Vezetéstudomány. 2013; 14(12): 44-53 (in Hungarian).

7. World Health Organization. Global recommendations on physical activity for health. Geneva: WHO; 2010.

8. Mayo X, Liguori G, Iglesias-Soler E, Copeland RJ, Clavel San Emeterio I, Lowe A, et al. The active living gender's gap challenge: 2013-2017 Eurobarometers physical inactivity data show constant higher prevalence in women with no progress towards global reduction goals. BMC Public Health. 2019; 19 (1): 1677. https://doi.org/10.1186/s12889-019-8039-8

9. Ács P, Prémusz V, Morvay-Sey K, Kovács A, Makai A, Elbert G. [Changes of sport and physical activity indicators in Hungary and in the European Union according to the results from recent years]. Sport Egészségt Füz. 2018; 2(1): 61-76 (in Hungarian).

10. Kustec S, Ličen S. Sport and welfare in Central and Eastern European countries. In: Porro NR, Martelli S, Testa A., editors. Sport, welfare and social policy in the European Union. London: Routledge; 2020. p. 132142. https://doi.org/10.4324/9781351118064-12

11. Földesi Szabó G, Egressy J. Post-transformational trends in Hungarian sport (1995-2004). Europ J Sport Soc. 2005; 2(2): 85-96. https://doi.org/10.1080/16138171.2005.11687770

12. Kovács K. Socio-cultural characteristics of sport activity among students in Central and Eastern Europe: comparative empirical analysis. J Phys Educ Sport. 2019; 19(1): 669-676.

13. Wicker P, Downward P, Lera-López F. Does regional disadvantage affect health-related sport and physical activity level? A multi-level analysis of individual behaviour. Eur J Sport Sci. 2017; 17(10): 1350-1359. https://doi.org/10.1080/17461391.2017.1376119

14. Van Tuyckom C, Scheerder J, Bracke P. Gender and age inequalities in regular sports participation: a crossnational study of 25 European countries. J Sports Sci. 2010; 28(10): 1077-1084.

https://doi.org/10.1080/02640414.2010.492229

15. Hovemann G, Wicker P. Determinants of sport participation in the European Union. Eur J Sport Soc. 2009; 6(1): 51-59. https://doi.org/10.1080/16138171.2009.11687827

16. Bartolj T, Slabe-Erker R. Differences in leisure time physical activity predictors in Europe. Polish Soc Rev. 2015; 190: 239-254.

17. European Commission. Eurobarometer - the citizens of the European Union and sport [Internet]. Brussels: European Commission; 2004 [cited 2020 Jun 16]. Available from: https://ec.europa.eu/commfrontoffice/ publicopinion/archives/ebs/ebs_213_report_en.pdf

18. European Commission. Eurobarometer - sport and physical activity [Internet]. Brussels: European Commission; 2010 [cited 2020 Jun 16]. Available from: http://ec.europa.eu/commfrontoffice/publicopinion/ archives/ebs/ebs_334_en.pdf

19. European Commission. Eurobarometer - sport and physical activity [Internet]. Brussels: European Commission; 2014 [cited 2020 Jun 16]. Available from: http://ec.europa.eu/commfrontoffice/publicopinion/ archives/ebs/ebs_412_en.pdf

20. European Commission. Eurobarometer - sport and physical activity [Internet]. Brussels: European Commission; 2018 [cited 2020 Jun 16]. Available from: http://ec.europa.eu/commfrontoffice/publicopinion/ index.cfm/survey/getsurveydetail/instruments/special/surveyky/2164

21. Harvey SB, Overland S, Hatch SL, Wessely S, Mykletun A, Hotopf M. Exercise and the prevention of depression: results of the HUNT cohort study. American Journal Psychiatry. 2017; 175: 28-36. https://doi.org/10.1176/appi.ajp.2017.16111223

22. Gémes K. [Sport and quality of life]. In: Kopp M, Kovács ME., editors. [Hungarian population's quality of life at the turn of the millennium]. Budapest: Semmelweis Publishing; 2006. p. 167-180 (in Hungarian).

23. Kovács A, Paár D, Elbert G, Welker Z, Stocker M, Ács P. [Survey of sports consumption habits of Hungarian households]. Pécs: Faculty of Health Sciences, University of Pécs; 2015 (in Hungarian).

24. Van Tuyckom C, Scheerder J. A multilevel analysis of social stratification patterns of leisure-time physical activity among Europeans. Science \& Sports. 2010; 26(6): 304-311. https://doi.org/10.1016/j.scispo.2010.04.003

25. Downward P, Lera-López F, Rasciute S. The correlates of sports participation in Europe. Eur J Sport Sci. 2014; 14(6): 592-602. https://doi.org/10.1080/17461391.2014.880191

26. World Health Organization. Physical activity factsheets [Internet]. Geneva: World Health Organization; 2018 [cited 2020 Jun 26]. Avaliable from: https://www.euro.who.int/en/health-topics/disease-prevention/ physical-activity/data-and-statistics/physical-activity-fact-sheets 
27. Nash L, Rocha P, Whiting S, World Health Organization. Development of a standardized physical activity and sport monitoring system for the European Union. Public Health Panorama. 2018; 4(3): 481-484.

28. Ruetten A, Frahsa A, Engbers L, Gusi N, Mota J, Pacenka R, et al. Supportive environments for physical activity, community action, and policy in 8 European Union member states: comparative analysis and specificities of context. J Phys Act Health. 2014; 11(5): 873-883. https://doi.org/10.1123/jpah.2012-0225

29. Buck C, Loyen A, Foraita R, Van Cauwenberg J, De Craemer M, Mac Donncha C, et al. Factors influencing sedentary behaviour: a system based analysis using Bayesian networks within DEDIPAC. PloS One. 2019; 14(1): e0211546. https://doi.org/10.1371/journal.pone.0211546

30. Lakerveld J, Loyen A, Schotman N, Peeters CFW, Cardon G, van der Ploeg HP, et al. Sitting too much: a hierarchy of socio-demographic correlates. Prev Med. 2017; 101: 77-83. https://doi.org/10.1016/j.ypmed.2017.05.015

31. Wicker P, Hallmann K, Breuer C. Micro and macro level determinants of sport participation. Sport, Busin Man Int J. 2012; 2: 51-68. https://doi.org/10.1108/20426781211207665

32. Eakins J. An analysis of the determinants of sports participation and time spent in different sporting contexts. Man Sp Leis. 2018; 23: 157-173. https://doi.org/10.1080/23750472.2018.1527713 